\title{
EDITORIAL
}

\section{Infección por virus de inmunodeficiencia humana en la mujer y en el niño}

\author{
HUMAN IMMUNODEFICIENCY VIRUS IN THE WOMAN AND THE INFANT
}

La infección por el virus de la inmunodeficiencia humana (VIH) ha alcanzado en el mundo cifras mucho mayores de lo esperado. Es así como los datos entregados por UNAIDS en diciembre del 2000 revelan que desde los inicios de la epidemia se han reportado casi 60 millones de personas con VIH/SIDA, cifra que no representa a los realmente infectados, cuyo número es muchísimo mayor. La cifra anterior comprende 21,8 millones de personas que han muerto por VIH/SIDA y 36,1 millones viviendo con la infección por VIH/SIDA.

Debido al aumento de la transmisión heterosexual y de la drogadicción femenina, ha habido también un aumento de mujeres y, en consecuencia, de niños con VIH/SIDA. A diciembre del 2000 habían muerto en el mundo 9 millones de mujeres y 4,3 millones de niños bajo 15 años de edad por VIH/SIDA y están viviendo con VIH/SIDA 16,4 millones de mujeres y 1,4 millones de niños bajo esa edad. En el mundo se infecta con VIH un niño por minuto. En estas cifras pesa el cómo se ha presentado la epidemia en países subdesarrollados, principalmente los países africanos.

En Chile desde 1984, año en que se diagnosticó el primer caso de VIH/SIDA, a diciembre de 1999, se han notificado alrededor de 7.500 personas con VIH/SIDA, cifra que representaría la quinta parte de los realmente infectados. De ellas han fallecido 2.327. Los principales grupos de edad afectados están entre los 20 y 49 años, la edad más productiva en trabajo y reproductiva sexualmente. En Chile se ha producido una tendencia a la feminización de la infección por VIH/SIDA; de las formas de contagio de la infección, la que más sistemáticamente ha crecido, es la transmisión heterosexual en mujeres y con ello ha habido un aumento de los casos de SIDA en mujeres. Alrededor de $10 \%$ de los casos de SIDA se han presentado en mujeres, $\sim 1,5 \%$ de los casos de SIDA se debe a transmisión vertical.

Esta tendencia a la feminización de la infección por VIH/SIDA presupone un aumento de mujeres embarazadas infectadas con VIH y con ello un aumento de niños infectados con VIH. A octubre del 2000 se habian detectado 483 mujeres embarazadas infectadas por VIH, con 124 hijos infectados.

Sin embargo, según estudios centinelas de CONASIDA, la prevalencia de la infección por VIH en mujeres embarazadas es aún baja en Chile ( $<0,04 \%$, es decir 1/2.000). Ello significa que el implementar la prueba de VIH como un examen de rutina en la embarazada es de un alto costo, difícil de asumir sólo por el MINSAL.

Por el contrario, la prueba del VIH permite detectar que una mujer embarazada está infectada con VIH y con ello ofrecerle medidas como la profilaxis antiretroviral, para prevenir su transmisión vertical.

La aplicación de la profilaxis antiretroviral con zidovudina (Protocolo ACTG 076) se inició en Chile a fines de 1994, comienzos del 95. Con su aplicación, más el ofrecimiento de 
cesárea electiva y lactancia artificial, se ha conseguido disminuir la transmisión vertical del $V I H$ desde la cifra histórica de $\sim 28 \%$, a algo más del 2\%, en estos últimos 2 años. En la actualidad casi la totalidad de los niños que el Comité de SIDA Pediátrico de la Sociedad Chilena de Pediatría (SOCHIPE) detecta con infección por VIH en Chile, son aquellos cuyas madres no han recibido profilaxis antiretroviral.

La mejor manera de prevenir la infección por VIH en niños es evitar el contagio de las mujeres o que las ya infectadas con VIH se embaracen, pero como ello no siempre es posible de lograr, debemos tratar de detectar a las mujeres embarazadas que están infectadas y ofrecerles medidas para prevenir la transmisión vertical del VIH, entre ellas la profilaxis antiretroviral

Es por ello que CONASIDA- MINSAL, implementará una Norma según la cual el equipo gineco-obstétrico tendrá la obligación de ofrecer la prueba de detección serológica de VIH a toda mujer embarazada, con consentimiento informado y con consejería pre y postprueba, pudiendo la mujer aceptarla o rechazarla. Esto hace que el costo del examen sea asumido por distintas entidades o por la embarazada y no sólo por el MINSAL. Si la mujer embarazada resulta estar infectada por el VIH, el equipo debe ofrecer profilaxis antiretroviral de la transmisión, la que sí será gratuita para todas, posibilidad de cesárea electiva y de lactancia artificial.

Con lo anterior, el Comité ad hoc de la SOCHIPE aspira a no continuar detectando, recién en el período post-natal, a los niños infectados con VIH. La detección tardía, por síntomas de enfermedad, implica un deterioro clínico, inmunológico y virológico que ya puede ser severo, tratamientos largos y costosos, no siempre fáciles de cumplir por las personas a cargo o riesgos de administración irregular por fallas en el suministro de los medicamentos.

Aún con las medidas profilácticas anteriormente nombradas, nacerán niños infectados con VIH pero, como estos niños serán seguidos desde el nacimiento, su manejo será más precoz y costo/beneficio favorable que el de los niños detectados tardíamente.

La SOCHIPE espera una pronta implementación de esta norma con el fin de lograr una disminución de niños infectados con VIH; también espera que con la consideración de la infección por VIH/SIDA como una enfermedad "compleja" y con su traspaso al Fondo Nacional de Salud (FONASA) en el 2001, se logre un manejo más adecuado y oportuno, evitando interrupciones en el suministro de medicamentos a todas las personas infectadas con VIH/SIDA, muy especialmente al binomio madre-hijo y a los niños.

En los artículos sobre VIH/SIDA que se presentan en esta revista se describe en detalle nuestra realidad acerca de esta patología en el binomio madre-hijo y en el niño.

Elba Wu $\mathrm{H}$.

Presidenta

Comité Nacional de SIDA Pediátrico

Sociedad Chilena de Pediatría. 